\title{
EEG $\mu$-RHYTHM REACTIVITY IN CHILDREN DURING IMITATION OF BIOLOGICAL AND NON-BIOLOGICAL MOTION
}

\author{
Kaida AI $\bowtie$, Mikhailova AA, Eismont EV, Dzhapparova LL, Pavlenko VB
}

V.I. Vernadsky Crimean Federal University, Simferopol, Russia

\begin{abstract}
The development of brain-computer interfaces based on the use of EEG sensorimotor rhythms reactivity parameters and designed for the rehabilitation of people (including children) with impaired motor functions is currently relevant. The study was aimed to analyse the EEG $\mu$-rhythm in the individual frequency range in children during imitation of biological and non-biological motion. EEG was recorded at frontal, central and parietal cortical regions in 136 normally developing right-handed children aged 4-15, at rest and during the execution and imitation of movements using the computer mouse. When the children moved the computer mouse on their own $\left(F_{1,132}=31.17 ; p<0.001\right)$ and executed the concentric moving of the coloured circle $\left(F_{1,132}=90.34 ; p<0.001\right)$, the $\mu$-rhythm desynchronization developed in the frontal, central and parietal neocortical regions. The $\mu$-rhythm synchronization was detected during the non-biologocal motion imitation $\left(F_{1,132}=12.65 ; p<0.001\right)$, compared to the task on the autonomous movement execution. The $\mu$-rhythm desynchronization was observed during the biologocal motion imitation in relation to autonomous movement execution $\left(F_{1132}=9.58 ; p=0.002\right)$. The described effects had their own features in the groups of children aged $4-6,7-9,10-12$ and $13-15$. The study results demonstrate the desirability of taking into account the $\mu$-rhythm reactivity age-related features and the visual stimuli nature when developing software for the brain-computer interfaces.
\end{abstract}

Keywords: children; EEG; $\mu$-rhythm; imitation; biological motion; non-biological motion

Funding: the study was performed as a part of the project "Development of a complex of exoskeleton, hands and procedures for the rehabilitation of children with cerebral palsy" supported by the Ministry of Science and Higher Education of Russian Federation (RFMEFI60519X0186).

Author contribution: Kaida Al — data acquisition and analysis, manuscript writing; Mikhailova AA — data analysis, manuscript writing; Eismont EV — research planning, data acquisition and analysis, manuscript writing; Dzhapparova LL — data acquisition, manuscript writing; Pavlenko VB - research planning, data analysis, manuscript writing.

Compliance with ethical standards: the study was approved by the Ethics Committee of V.I. Vernadsky Crimean Federal University (protocol № 12 dated June 14, 2016). Informed consent to participation in the study was obtained from the parents.

$\square$ Correspondence should be addressed: Anna I. Kaida Angarskaya, 38, Simferopol, 295001; kaydaanna@gmail.com

Received: 01.04.2019 Accepted: 15.04.2020 Published online: 16.04.2020

DOI: 10.24075/brsmu.2020.019

\section{РЕАКТИВНОСТЬ $\mu$-РИТМА ЭЭГ У ДЕТЕЙ ПРИ ИМИТАЦИИ ДВИЖЕНИЙ ВИЗУАЛЬНЫХ ОБРАЗОВ БИОЛОГИЧЕСКОГО И НЕБИОЛОГИЧЕСКОГО ПРОИСХОЖДЕНИЯ}

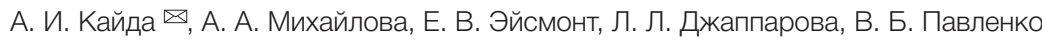

Крымский федеральный университет имени В. И. Вернадского, Симферополь, Россия

\begin{abstract}
В настоящее время актуальна разработка интерфейсов мозг-компьютер, основанных на использовании параметров реактивности сенсомоторных ритмов ЭЭГ и предназначенных для реабилитации людей с нарушениями двигательных функций, в том числе детей. Целью работы было проанализировать реактивность $\mu$-ритма ЭЭГ в индивидуально определенном частотном диапазоне у детей при имитации движений визуальных образов биологического и небиологического происхождения. ЭЭГ регистрировали во фронтальных, центральных и париетальных областях коры у 136 нормально развивающихся детей-правшей 4-15 лет в состоянии двигательного покоя, а также при самостоятельном выполнении и имитации движений с помощью компьютерной мыши. При выполнении детьми самостоятельных движений компьютерной мышью $\left(F_{1,132}=31,17 ; p<0,001\right)$ v при осуществлении концентрических перемещений цветного круга $\left(F_{1,132}=90,34 ; p<0,001\right)$ развивается десинхронизация $\mu$-ритма во фронтальных, центральных и париетальных областях неокортекса. При имитации движений визуальных образов небиологического происхождения, по сравнению с заданием на выполнение самостоятельных движений, была выявлена синхронизация $\mu$-ритма $\left(F_{1,132}=12,65 ; p<0,001\right)$. При подражании движениям визуальных образов биологического происхождения относительно самостоятельных движений выявлена десинхронизация $\mu$-ритма $\left(F_{1,132}=9,58 ;\right.$ p = 0,002). Данные эффекты имели свои особенности в группах детей 4-6, 7-9, 10-12 и 13-15 лет. Результаты исследования показывают целесообразность учета возрастных особенностей реактивности н-ритма и характера предъявляемых зрительных стимулов при разработке программного обеспечения интерфейсов мозг-компьютер.
\end{abstract}

Ключевые слова: дети; ЭЭГ; н-ритм; имитация; биологическое движение; небиологическое движение

Финансирование: исследования выполнены в рамках темы: «Разработка комплекса экзоскелета кисти с внешним программным управлением и биологической обратной связью для процедуры реабилитации детей с синдромом ДЦП» при финансовой поддержке Министерства науки и высшего образования Российской Федерации (RFMEFI60519X0186)

Вклад авторов: А. И. Кайда - набор и обработка данных, написание статьи; А. А. Михайлова - обработка данных, написание статьи; Е. В. Эйсмонт план исследований, набор и обработка данных, написание статьи; Л. Л. Джаппарова - набор данных, написание статьи; В. Б. Павленко - план исследований, обработка данных, написание статьи.

Соблюдение этических стандартов: исследование одобрено этическим комитетом ФГАОУ ВО «Крымский федеральный университет им. В. И. Вернадского» (протокол № 12 от 14 июня 2016 г.). Получено добровольное информированное согласие родителей на участие детей в эксперименте.

$\bowtie$ Для корреспонденции: Анна Ивановна Кайда

ул. Ангарская, д. 38, г. Симферополь, 295001; kaydaanna@gmail.com

Статья получена: 01.04.2019 Статья принята к печати: 15.04.2020 Опубликована онлайн: 16.04.2020

DOI: $10.24075 /$ vrgmu.2020.019

The human's ability to understand the goal of action and imitate is necessary for effective integration into the social environment, allowing one to master various types of activities and norms of behavior in society. The mirror neuron system (MNS) 
is important for recognition of movements and associated intentions. Mirror neurons are neurons able to activate in a similar way, both when executing actions, and when watching other individuals executing similar actions [1, 2]. It has been suggested that MNS plays an important role in the complex forms of social interaction. [3].

Desynchronization of the EEG sensorimotor rhythm, the $\mu$-rhythm, is considered to be a marker of MNS activation [4]. Since modulations of the $\alpha$-rhythm in the occipital region can overlap the effects of $\mu$-rhythm desynchronization [5], to determine the individual frequency range and reactivity, the following features are taken into account: unlike the occipital $\alpha$-rhythm, the $\mu$-rhythm is most pronounced in the frontoparietal regions; the $\mu$-rhythm amplitude decreases when the subject moves, imagines movement or watches the other subjects' movement, but does not change significantly when the subject opens or closes the eyes [6, 7].

Sensorimotor rhythm amplitude depression during the biological motion watching is more pronounced than during watching the non-biological motion [8], which is also characteristic of watching social actions, compared to actions outside the social context [9]. Regarding the movement imitation, it is assumed that imitation is associated with the activation of human MNS, and is the result of the comparison of the observed action and the internal motor plan for the execution of action [10].

The study of MNS and $\mu$-rhythm reactivity is of special interest in a view of new methods development for rehabilitation of patients with various motor impairments using braincomputer interfaces [11, 12]. In particular, in the treatment of adult patients, the synchronous interfaces are used, based on the analysis of the EEG sensorimotor rhythms reactivity when representing the movement in response to the signal presented $[13,14]$. Recently, such methods are beginning to be used for rehabilitation of children with cerebral palsy [15]. Symbols or text commands are reported to be used as the signals presented to patients. However, the concept of MNS suggests that stimuli visually representing movements and requiring the simulation of movements could be more effective for triggering reactions in the EEG $\mu$-rhythm range. It should be noted that when working with children it is preferable to use the actions that are in the child's motor repertoire for more effective task execution [16]. The study was aimed to analyse the EEG $\mu$-rhythm under conditions of biological and non-biological motion imitation in children aged 4-15 using the computer pointer device, the mouse. Now, even the preschool children are familiar with the computer mouse operation.

\section{METHODS}

\section{Characteristics of a sample}

The study was performed at the Center for Collective Use of Scientific Equipment "Experimental physiology and biophysics" of V.I. Vernadsky Crimean Federal University.

The study included 136 righ-handed children aged 4-15 (69 boys and 67 girls). Inclusion criteria: normal (or corrected to normal) vision and hearing; preferred right hand when operating the computer mouse; sufficient degree of cognitive development (IQ at least 80 points according to the Wechsler scale, variants WPPSI and WISC). Exclusion criteria: taking the CNS affecting drugs; severe chronic somatic diseases. The children were divided into four age groups: 4-6 years (30 people), 7-9 years (46 people), 10-12 years (30 people) and 13-15 years (30 people).

\section{EEG recording}

EEG recording was performed using the Neuron-Spectrum-3 EEG System (Neurosoft; Russia). Data were obtained using the WinEEG version 2.8 software (available for free). Independent component analysis was used for the artifacts correction. The 19 monopolar EEG electrodes were used in accordance with the 10-20 system. In our study, the frontal, central and parietal neocortical regions were the area of concern (F3, F4, Fz, C3, C4, Cz, P3, P4, Pz loci). Paired electrodes attached to the the ear lobes were the reference electrode. Cut-off frequencies of the high and low pass filters were 1.5 and $35 \mathrm{~Hz}$, respectively, EEG digitization rate was $250 \mathrm{~Hz}$.

EEG recording was performed while the children performed a queue of sequential tasks, the duration of each task was $30 \mathrm{~s}$. EEG segments were processed using the Fast Fourier Transform with the 4 epoch of analysis and 50\% mutual overlapping of epochs.

To imitate the non-biological motion, the following tasks were used:

1) gaze fixation on the video of the computer mouse (baseline);

2) concentric moving of the coloured circle on the monitor screen using the computer mouse (Mn.1) (Fig. 1A);

3) imitation of the other coloured circle's motion (imitation of non-biological motion, ImNB) (Fig. 1B).

When imitating the biological motion, the subject and the researcher were located at the tables next to each other (the researcher on the right), each of tables had a monitor and a computer mouse on it. Using the webcam, the working plane of the researcher's table with the mouse on it was demonstrated on the monitor in front of the subject. The tasks queue was as follows:

1) gaze fixation on the video of the computer mouse (baseline);
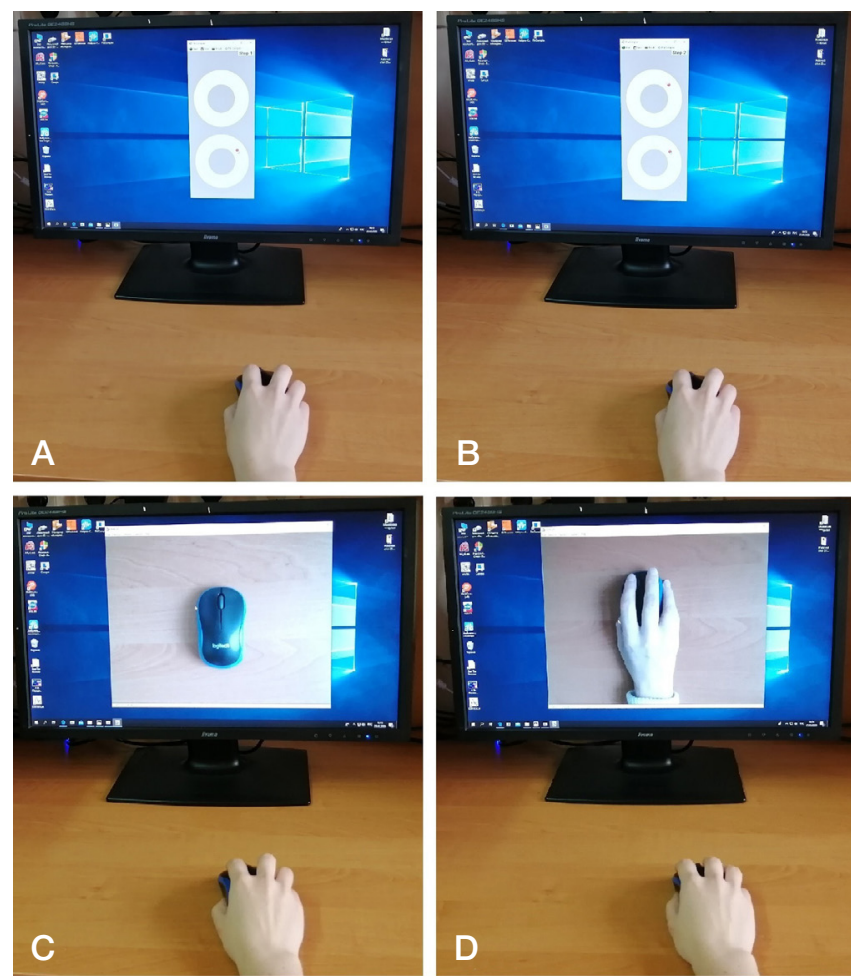

Fig. 1. Task queue. A. Concentric colored circle moving on the monitor screen using the computer mouse (Mn.1). B. Imitation of other colored circle's movement (ImNB). C. Children move the computer mouse in circle on their own (Mn.2). D. Children imitate the researcher's movements $(\mathrm{ImB})$ 
2) moving the computer mouse in a circle by children on their own (Mn.2) (Fig. 1C);

3) imitation of the researcher's movements by the children (imitation of biological motion, ImB) (Fig. 1D).

EEG was analysed in the individual $\mu$-rhythm frequency range defined when the subject moved his right hand on his own (C3). The full frequency range of the $\mu$-rhythm $(6-13 \mathrm{~Hz})$ was divided into segments of $1 \mathrm{~Hz}$. As an individual frequency range, two adjacent segments were taken with maximum desynchronization in relation to baseline [17]. The $\mu$-rhythm amplitude within the individual frequency range was calculated for each experimental situation. Log transformation was used for normalization of the amplitude values distribution.

Reactivity indices were used for comparison of $\mu$-rhythm parameters under conditions of biological and non-biological movement imitation. These indices were calculated according to the generally accepted scheme [18] using the following formula: $k=\ln (B / A)$, where $k$ is the sensorimotor rhythm reactivity index, $B$ is the sensorimotor rhythm amplitude in the major situation, and $A$ is the sensorimotor rhythm amplitude in the initial reference situation (baseline or subjects' moving on their own). Positive reactivity index values corresponded to synchronization of the sensorimotor rhythm, and negative values corresponded to desynchronization.

\section{Statistical analysis}

Statistical analysis was performed using the STATISTICA 12.0 software (StatSoft Inc.; USA). To describe the non-normal distributions, median and interquartile range were used, the differences between the groups were evaluated using the Mann-Whitney U-test. For normal data distribution, the mean and standard error of the mean were used. The differences of the amplitude and reactivity indices of the $\mu$-rhythm recorded in different experimental situations were evaluated by the repeated measures ANOVA. The $4 \times 2 \times 9$ scheme was used for assessment of the one intersubjective factor (age group, AGE) and two intrasubjective factors (situation, SIT, and locus, $\mathrm{LOC}$ ) influence. To calculate the statistical significance of the sensorimotor rhythm differences in relation to each of the nine

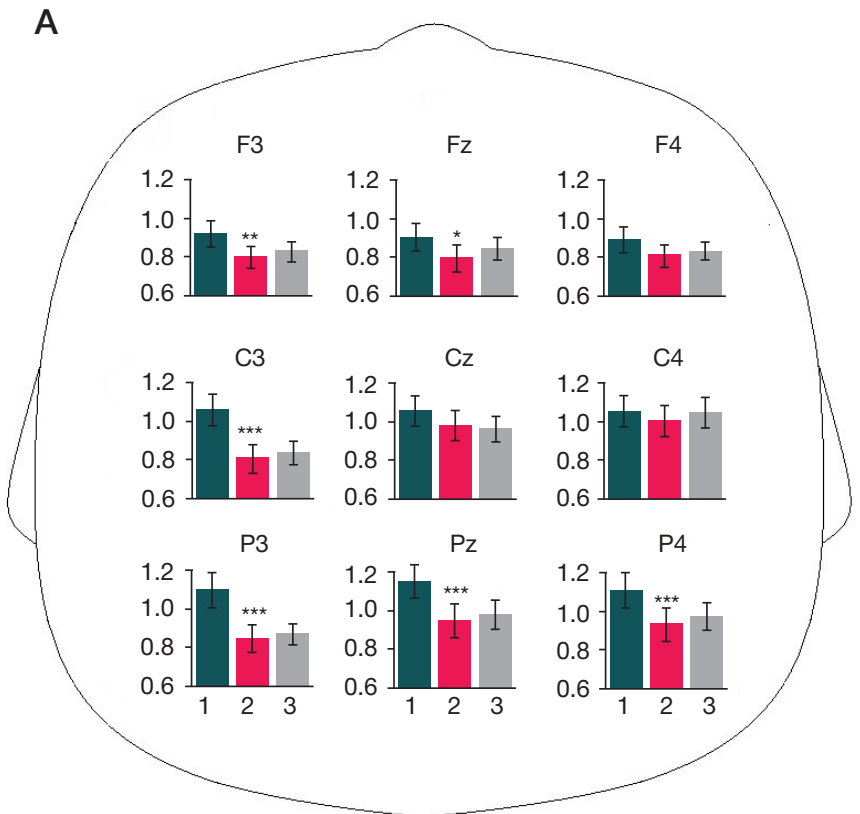

EEG derivations within each age group, the ad-hoc analysis method (F-distribution estimation) was used.

\section{RESULTS}

\section{$\mu$-rhythm frequency parameters}

The median values of the individual $\mu$-rhythm range lower boundary were $9 \mathrm{~Hz}(8.5 ; 10)$, the extreme values were 6 and $11 \mathrm{~Hz}$. The median values of the individual $\mu$-rhythm range upper boundary were $11 \mathrm{~Hz}(10.5 ; 12)$, and the extreme values were 8 and $13 \mathrm{~Hz}$. The differences between the age groups were not significant.

\section{EEG $\mu$-rhythm amplitude at rest and under condition of motion execution and imitation}

The $\mu$-rhythm amplitude differences analysis of variance in the Mn.1 situation in relation to baseline taking into account the age group and EEG locus revealed the sifnificant influence of the SIT $\left(F_{1,132}=90.34 ; p<0.001\right)$, AGE $\left(F_{3,132}=10.18\right.$; $p<0.001)$ and LOC $\left(F_{8,1056}=73.06 ; p<0.001\right)$ factors, as well as the SIT $\times$ LOC interaction $\left(F_{8,1056}=41.28 ; p<0.001\right)$. Compared to Mn.1, in the ImNB situation the SIT $\left(F_{1,132}=\right.$ 12.65; $p<0.001)$, AGE $\left(F_{3,132}=14.67 ; p<0.001\right)$ and LOC $\left(F_{8,1056}=39.43 ; p<0.001\right)$ factors significantly affected the $\mu$-rhythm amplitude changes.

The $\mu$-rhythm amplitude differences analysis of variance in the $\mathrm{Mn} .2$ situation in relation to baseline taking into account the age group and EEG locus revealed the sifnificant influence of the SIT $\left(F_{1,132}=31.17 ; p<0.001\right)$, AGE $\left(F_{3,132}=6.46\right.$; $p<0.001)$ and LOC $\left(F_{8,1056}=71.55 ; p<0.001\right)$, factors, as well as the SIT $\times$ LOC $\left(F_{8,1056}^{8,1056}=28.32 ; p<0.001\right)$ and SIT $\times$ AGE $\left(F_{3,132}=6.35 ; p<0.001\right)$ interactions. Evaluation of the $\mu$-rhythm amplitude changes in the ImB situation in relation to $\mathrm{Mn} .2$ revealed the significant influence of the SIT $\left(F_{1,132}=\right.$ 9.58; $p=0.002)$, AGE $\left(F_{3,132}=18.63 ; p<0.001\right)$ and LOC $\left(F_{8,1056}=54.08 ; p<0.001\right)$ factors, as well as the SIT $\times$ LOC $\left(F_{8,1056}^{8,1056}=3.28 ; p=0.001\right)$ and $\operatorname{SIT} \times \operatorname{AGE}\left(F_{3,132}=6.2\right.$; $p=0.001)$ interactions

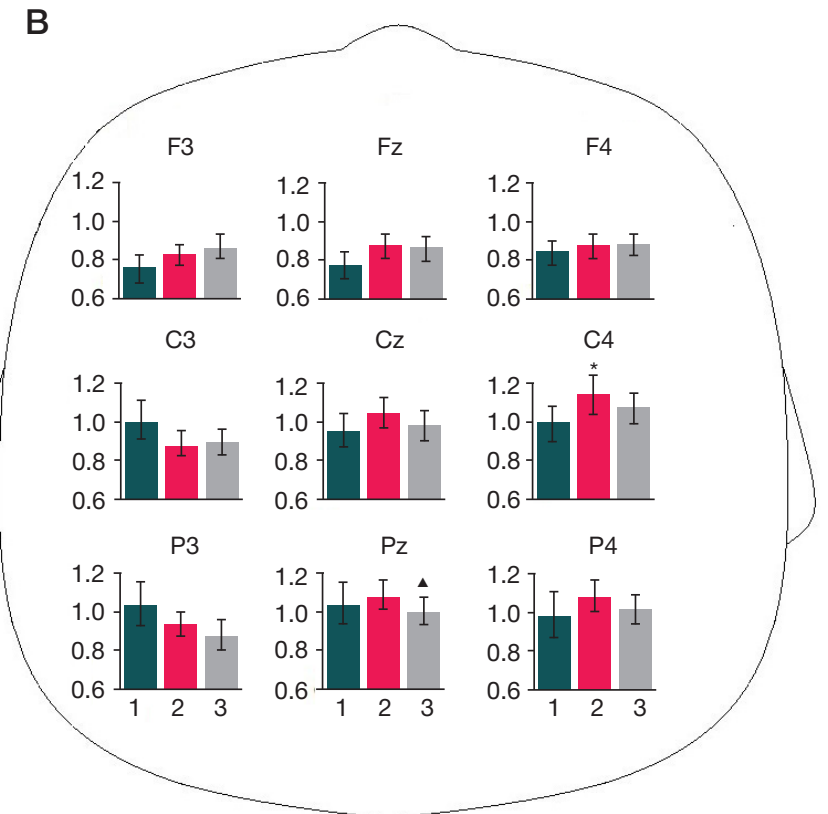

Fig. 2. EEG $\mu$-rhythm amplitude (A, Ln $\mu \mathrm{V}$ ) in children aged 4-6 during imitation of non-biological (A) and biological (B) motion. 1 - baseline, 2 - autonomous movements' execution at arbitrary speed, 3 - motion imitation. Amplitude differences between baseline and autonomous movements' execution: * $-p<0.05$; ${ }^{*}$ $p \leq 0.01 ;{ }^{* \star \star}-p \leq 0.001$; when executing autonomous movements and imitating: ${ }^{\star}-p<0.05$ 
In children aged 4-6 executing the concentric moving of the coloured circle, the significant EEG $\mu$-rhythm desynchronization was detected (Mn.1 in relation to baseline) in most studied regions. The $\mu$-rhythm amplitude changes in children imitating the coloured circle movement (ImNB in relation to $\mathrm{Mn}$.1) were not significant (Fig. 2A). When the children of that age moved the computer mouse on their own, the significant EEG $\mu$-rhythm amplitude increase (Mn.2 in relation to baseline) was detected in the the right hemisphere central locus (C4). When the children imitated the researcher's movements, the sensorimotor rhythm desynchronization (ImB in relation to $\mathrm{Mn}$.2) was registered in the B mid-parietal locus (Pz) (Fig. 2B).

In the group of children aged 7-9, the significant depression of $\mu$-rhythm in the Mn.1 situation was observed in most studied regions. In the ImNB situation (in relation to $\mathrm{Mn} .1$ ) the $\mu$-rhythm amplitude changes were not significant (Fig. 3A).
In the Mn.2 situation the significant sensorimotor rhythm desynchronization was detected in the central (C3 and $\mathrm{Cz}$ ) and all parietal loci. In the ImB situation (in relation to $\mathrm{Mn}$.2) there were no significant $\mu$-rhythm amplitude changes (Fig. 3B).

In children aged 10-12, in the Mn.1 sitiation the significant $\mu$-rhythm suppression was detected in most studied loci. During the coloured circle movement imitation the significant sensorimotor rhythm synchronization (ImNB in relation to Mn.1) was detected in the mid-frontal locus (Fig. 4A). In the Mn.2 situation the significant decrease in $\mu$-rhythm amplitude was observed in the central (C3 и Cz) and all parietal loci. In the ImB situation (in relation to $\mathrm{Mn} .2$ ) there were no significant sensorimotor rhythm amplitude changes (Fig. 4B).

In the group of teenagers aged 13-15, in the Mn.1 sitiation the significant $\mu$-rhythm suppression was observed in most studied loci. During the non-biological motion imitation (ImNB in relation to Mn.1) the significant sensorimotor rhythm
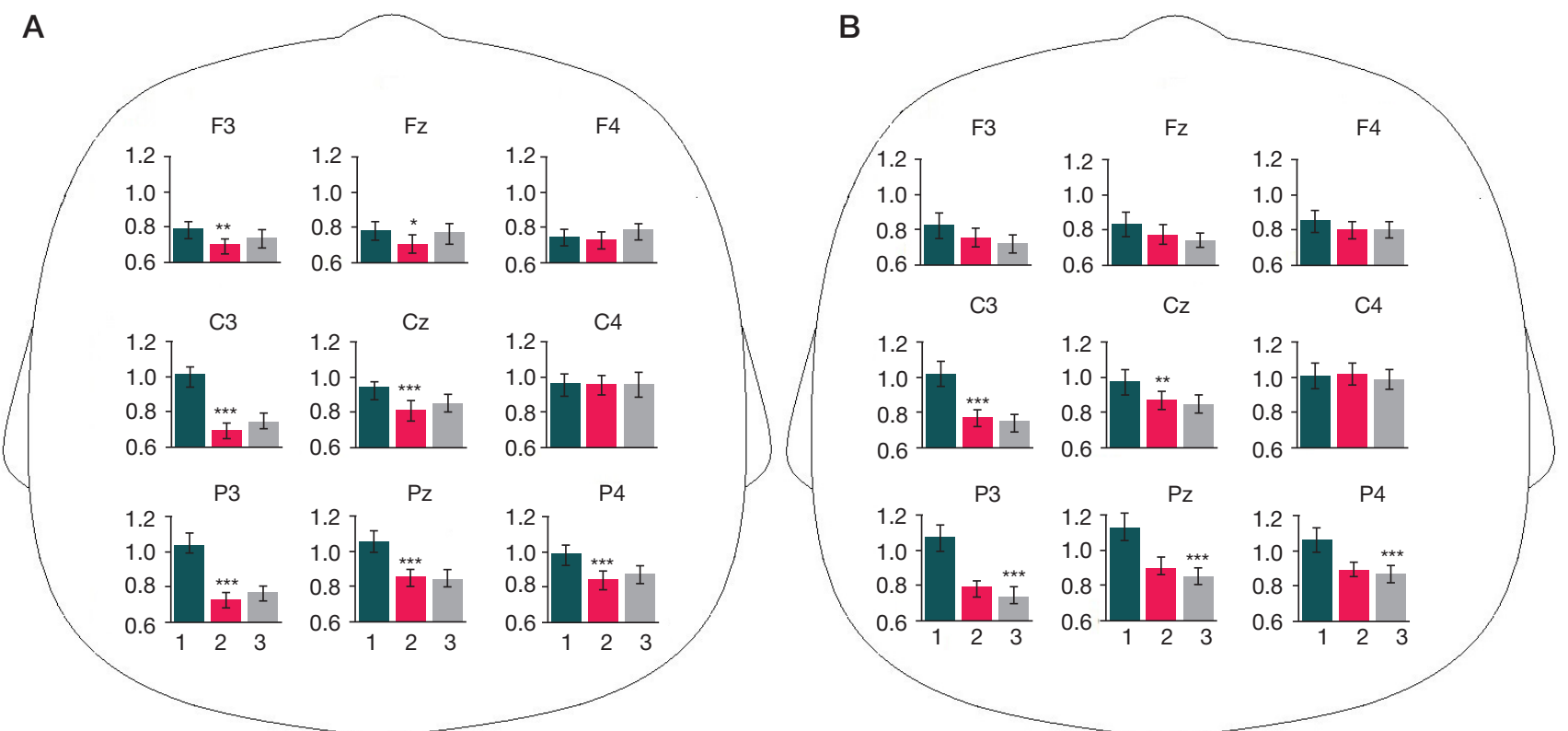

Fig. 3. EEG $\mu$-rhythm amplitude $(\mathrm{A}, \mathrm{Ln} \mu \mathrm{V})$ in the group of children aged 7-9 during imitation of non-biological $(\mathbf{A})$ and biological $(\mathbf{B})$ motion. The remaining notation is the same as in Fig. 2
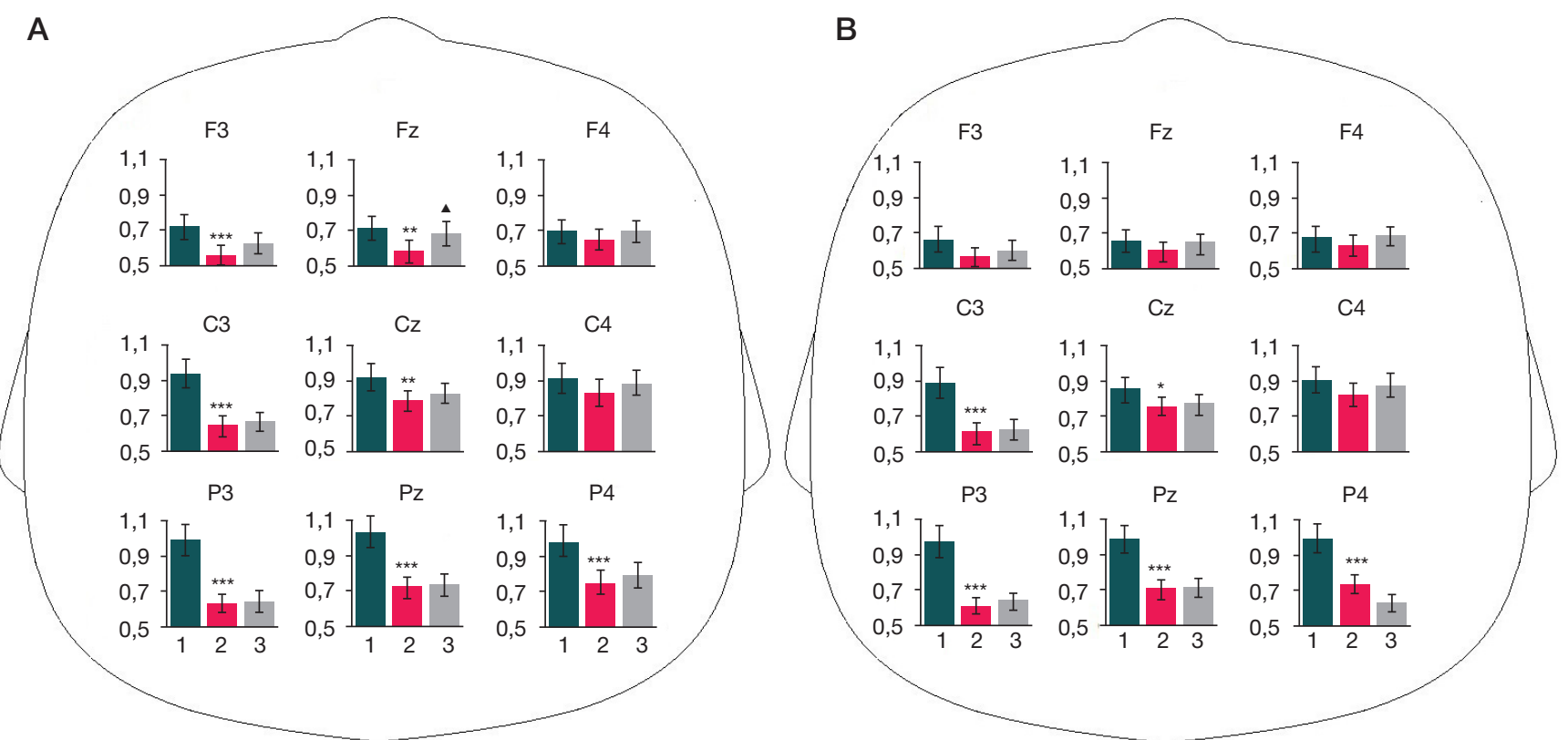

Fig. 4. $E E G \mu$-rhythm amplitude $(A, L n \mu V)$ in the group of children aged 10-12 during imitation of non-biological $(\mathbf{A})$ and biological (B) motion. The remaining notation is the same as in Fig. 2 
synchronization was detected in most studied regions (Fig. 5A). When the subjects moved the computer mouse on their own, significant sensorimotor rhythm desynchronization (Mn.2 in relation to baseline) was registered in all studied regions. In the ImB situation, the additional (compared to previous task) $\mu$-rhythm desynchronization was observed that was significant in all loci (Fig. 5B).

\section{EEG $\mu$-rhythm reactivity comparison under conditions of biological and non-biological motion imitation}

To evaluate the differences of $\mu$-rhythm reactivity in the ImNB and ImB situations (compared to execution of movements by children on their own at arbitrary speed), the reactivity indices analysis of variance was performed taking into account the age group and EEG locus. The mean $\mu$-rhythm reactivity index values for children of four age groups are presented in Tables 1 and 2. The significant impact of SIT $\left(F_{1,132}=21.85 ; p<0.001\right)$ and LOC $\left(F_{8,1056}=3.95 ; p<0.001\right)$ factors, as well as the SIT×AGE interaction $\left(F_{3,132}=5.52 ; p=0.001\right)$ was revealed In the group of pre-school children, the significant $\mu$-rhythm reactivity indices differences in the $\operatorname{ImNB}$ and $\operatorname{ImB}$ situations were detected in the parietal loci Pz and P4 ( $p=0.03)$. In children aged 7-9, the significant differences were observed in the locus Fz $(p=0.04)$. In children aged 10-12, no significant $\mu$-rhythm reactivity indices differences were detected. In the group of teenagers aged 13-15, the differences were significant in all studied regions $(p \leq 0.001)$.

\section{DISCUSSION}

According to the study results, the individual sensorimotor rhythm frequency ranges of the 4-15 years old children vary widely, and there are no significant differences in the mean values between different age groups. In the other authors's paper [19] reporting the EEG $\mu$-rhythm reactivity analysis in the selected frequency range in children aged 4-11, the average sencorimotor rhythm band was 9-11 Hz. High sensorimotor rhythm parameters variability among the individuals and no association with the children's age were detected. These indicate the need to determine the children's individual frequency range when studying the sensorimotor rhythm reactivity, as well as when attempting the correction using the $\mu$-rhythm parameters (EEG based neurofeedback training, correction using the brain-computer interface).

Analysis of the $\mu$-rhythm amplitude changes demonstrated that in 4-6 years old children arbitrarily moving the coloured circle (Mn.1) the significant EEG $\mu$-rhythm desynchronization in the frontal and central loci of left hemisphere, as well as in the median frontal and all parietal loci (F3, Fz, C3, P3, Pz, P4) could be detected. The results of our study are consistent with the literature data on the sensorimotor rhythm desynchronization during the voluntary movements' execution [20]. When the children moved the computer mouse on their own (Mn.2), no significant $\mu$-rhythm amplitude decrease was observed. It is possible that for children of this age, the task of relatively simple circular movements' execution with a computer mouse was simpler than the task of capturing and moving a colored circle using the computer mouse left button, and it did not require any special motor control. During the task execution, the significant EEG $\mu$-rhythm amplitude increase in the locus C4 was registered, which could be due to inhibition of the ipsilateral hemisphere (in relation to the hand used) [21].

In the groups of children aged 7-9 and 10-12 executing the movements on their own, the $\mu$-rhythm desynchronization was detected in most studied regions. The concentric coloured circle moving (Mn.1) unlike the mouse moving in a circle (Mn.2) was also associated with the sensorimotor rhythm desynchronization in the frontal loci (F3, Fz). It is known that the frontal cortical regions are responsible for planning and preparation of complex movements [22]. It is also assumed that more complex motor actions are accompanied by a more widespread $\mu$-activity desynchronization [23]. Presumably, moving the color circle in the group of 7-12 years old children, as well as in the group of younger children, required considerable effort, which led to the involvement of the cerebral cortex frontal region.

The situations of biological and non-biological motion imitation in children aged 4-6, 7-9 and 10-12 were associated with almost no additional modulation of the $\mu$-rhythm in relation to the arbitrary movements' execution. This may indicate that in children of said age the required for processing
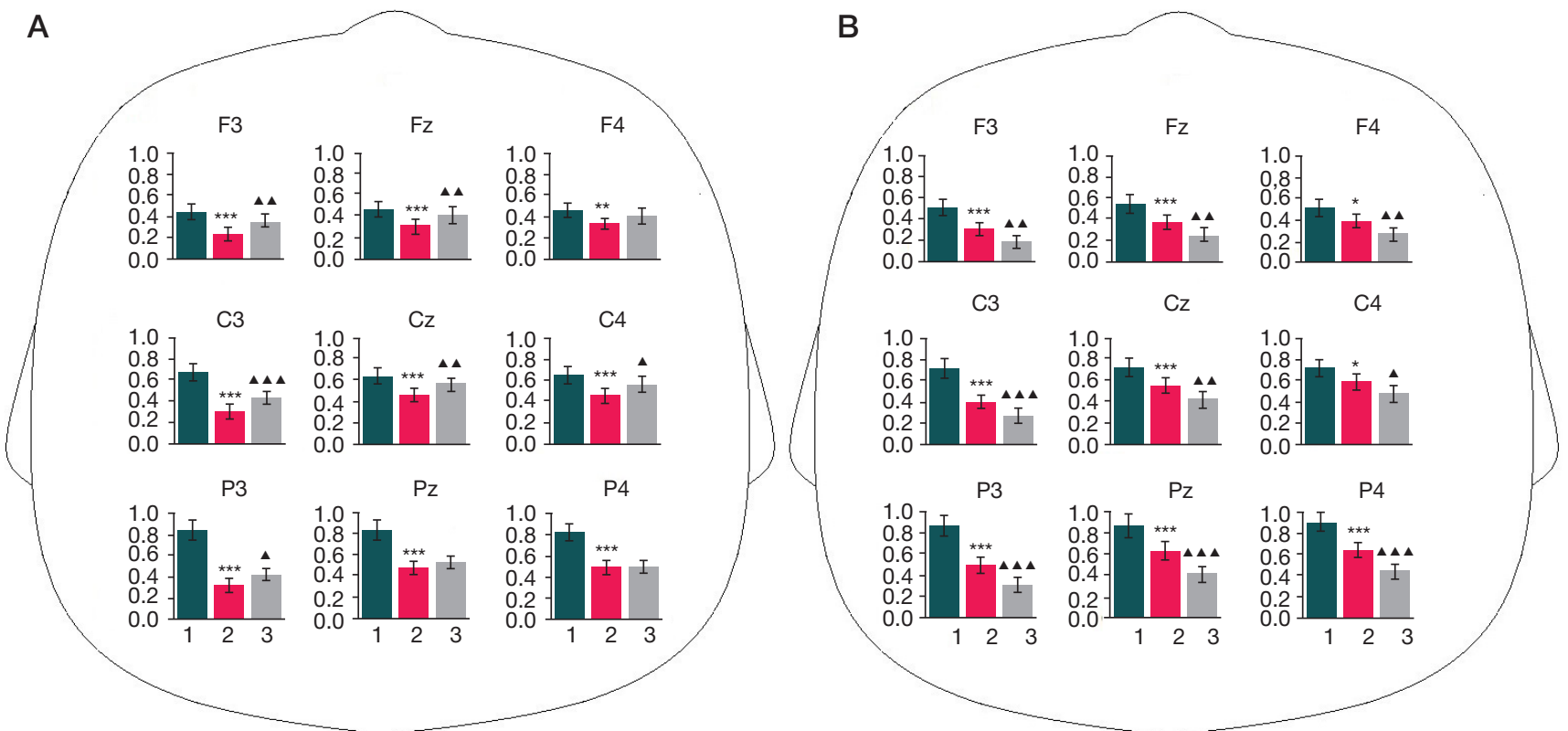

Fig. 5. EEG $\mu$-rhythm amplitude (A, Ln $\mu \mathrm{V}$ ) in the group of children aged 13-15 during imitation of non-biological (A) and biological (B) motion. Amplitude differences when executing autonomous movements and imitating: $\mathbf{\wedge}-p \leq 0.01 ; \mathbf{A \Delta}-p \leq 0.001$. The remaining notation is the same as in Fig. 2 
ОРИГИНАЛЬНОЕ ИССЛЕДОВАНИЕ І НЕЙРОФИЗИОЛОГИЯ

Table 1. Reactivity indices mean values (together with standard error of the mean) obtained during imitation of non-biological motion

\begin{tabular}{|c|c|c|c|c|c|c|c|c|c|}
\hline \multirow{2}{*}{ Group } & \multicolumn{7}{|c|}{ EEG electrodes } \\
\cline { 2 - 10 } & F3 & Fz & F4 & C3 & Cz & C4 & P3 & Pz & P4 \\
\hline 4-6 years & $0.03 \pm 0.04$ & $0.04 \pm 0.04$ & $0.03 \pm 0.03$ & $0.03 \pm 0.04$ & $-0.02 \pm 0.04$ & $0.04 \pm 0.03$ & $0.02 \pm 0.04$ & $0.03 \pm 0.04$ & $0.04 \pm 0.04$ \\
\hline 7-9 years & $0.05 \pm 0.03$ & $0.06 \pm 0.03$ & $0.05 \pm 0.03$ & $0.05 \pm 0.03$ & $0.04 \pm 0.03$ & $0.00 \pm 0.05$ & $0.04 \pm 0.03$ & $-0.01 \pm 0.03$ & $0.03 \pm 0.03$ \\
\hline 10-12 years & $0.06 \pm 0.04$ & $0.09 \pm 0.04$ & $0.05 \pm 0.04$ & $0.03 \pm 0.04$ & $0.04 \pm 0.03$ & $0.06 \pm 0.03$ & $0.01 \pm 0.04$ & $0.01 \pm 0.04$ & $0.05 \pm 0.05$ \\
\hline 13-15 years & $0.11 \pm 0.04$ & $0.11 \pm 0.05$ & $0.07 \pm 0.04$ & $0.12 \pm 0.03$ & $0.10 \pm 0.03$ & $0.11 \pm 0.04$ & $0.09 \pm 0.03$ & $0.05 \pm 0.03$ & $0.01 \pm 0.03$ \\
\hline
\end{tabular}

Note: positive reactivity index values correspond to sensorimotor rhythm synchronization, negative values correspond to desynchronization.

Table 2. Reactivity indices mean values (together with standard error of the mean) obtained during imitation of biological motion

\begin{tabular}{|c|c|c|c|c|c|c|c|c|c|}
\hline \multirow{2}{*}{ Group } & \multicolumn{7}{|c|}{ EEG electrodes } \\
\cline { 2 - 10 } & F3 & Fz & F4 & C3 & Cz & C4 & P3 & Pz & P4 \\
\hline 4-6 years & $0.04 \pm 0.04$ & $-0.01 \pm 0.05$ & $0.01 \pm 0.05$ & $0.01 \pm 0.04$ & $-0.07 \pm 0.05$ & $-0.07 \pm 0.06$ & $-0.06 \pm 0.05$ & $-0.09 \pm 0.05$ & $-0.06 \pm 0.06$ \\
\hline 7-9 years & $-0.03 \pm 0.03$ & $-0.04 \pm 0.03$ & $0.00 \pm 0.03$ & $-0.03 \pm 0.02$ & $-0.03 \pm 0.03$ & $-0.03 \pm 0.04$ & $-0.04 \pm 0.04$ & $-0.06 \pm 0.03$ & $-0.03 \pm 0.03$ \\
\hline 10-12 years & $0.04 \pm 0.05$ & $0.04 \pm 0.04$ & $0.06 \pm 0.04$ & $0.03 \pm 0.03$ & $0.01 \pm 0.03$ & $0.06 \pm 0.04$ & $0.03 \pm 0.03$ & $0.01 \pm 0.04$ & $0.05 \pm 0.03$ \\
\hline 13-15 years & $-0.11 \pm 0.03$ & $-0.12 \pm 0.03$ & $-0.11 \pm 0.03$ & $-0.14 \pm 0.03$ & $-0.12 \pm 0.04$ & $-0.11 \pm 0.04$ & $-0.18 \pm 0.03$ & $-0.21 \pm 0.04$ & $-0.20 \pm 0.03$ \\
\hline
\end{tabular}

multimodal information additional neocortical resources are not sufficiently involved under the conditions of imitation.

In the group of teenagers aged 13-15, the significant sensorimotor rhythm desynchronization during the autonomous movements' execution was detected in all studied regions. The $\mu$-rhythm amplitude decrease above the frontal, central and parietal loci in elder children may be due to development of connections between the neocortical regions involved. During the non-biological motion imitation a smaller drop in the sensorimotor rhythm amplitude was observed than during the autonomous movements execution and biological motion imitation (which is especially pronounced in the frontal and central loci). It can be assumed, that the need to imitate the movements of another object (colored circle) led to the shift of attention to its perception and, as a result, to weakening of one's own movements' motor control. In children of this age, in the ImB situation, the additional (compared to the observed during the Mn.2 task execution) significant $\mu$-rhythm desynchronization in all loci was detected. The more pronouced reaction in the parietal loci is noteworthy. It is known, that parietal cortical regions are involved into the information processing during watching the human's motion (compared to watching the non-biological objects' motion) [24]. The sensorimotor rhythm modulation, revealed by us in the described regions during the biological motion imitation, may be due to involvement of the parietal cortex MNS components responsible for coding of goals underlying the watched movements [25]. The mirror neurons are associated with the cognitive integration of visual, auditory and motor stimuli needed for social interaction in children [26] and adults [27]. Thus, it can be assumed, that the additional $\mu$-rhythm desynchronization during the other man's movements imitation is caused precisely by the social context to which the MNS is sensitive.

Comparison of the $\mu$-rhythm reactivity indices for imitation tasks revealed that the biological motion imitation in elder children was associated with the greater desynchronization, compared with the situation of color circle movements' imitation. As already noted, similar features of the sensorimotor rhythm reactivity during watching the biological and non-biological objects movements were detected in adult volunteers [8].

A sensorimotor rhythm reactivity patterns comparative analysis in children of different ages allows us to come to a number of conclusions. In the group of youngest children (4-6 years), the most pronounced activation of the frontal, central and parietal cortical regions, manifested in the $\mu$-rhythm amplitude decrease (more pronounced in the left hemisphere), is observed during computer mouse operation associated with a non-biological motion (coloured circle) (Mn.1). Random rhythm computer mouse movements' execution (Mn.2) does not lead to the significant decrease in the $\mu$-rhythm amplitude, and the biological motion imitation (the other person's hand movement) is not associated with any additional activation in most loci. Thus, in the described experimental situation, in pre-school children, the cortical center of motor analyzer is especially sensitive to manipulations with biological objects. In elder children (7-9 and 10-12 year), a similar neocortical activation pattern was revealed during execution of movements associated with non-biological objects, computer mouse moving and biological object (researcher's hand) motion imitation. Unlike the previously described groups, the children aged 13-15 demonstrate the significant $\mu$-rhythm desynchronization in the frontal, central and parietal cortical regions of both hemispheres during imitation of the other person's motion.

It stands to reason, that processes of perception and other person's movement imitation in younger children are in their infance, and in teenagers, these processes are rather developed and similar to those in adults. In teenagers, the pronounced $\mu$-rhythm desynchronization in all studied regions during moving on their own or imitating the biological visual images motion may be due to maturation of motor, sensorimotor and associative cortical regions involved in the execution and imitation of movements [28]. The revealed agerelated sensorimotor rhythm reactivity features may be used for improvement of existing rehabilitation techniques based on the EEG-controlled robotic systems for children with cerebral palsy [15].

\section{CONCLUSION}

When children aged 4-15 move the computer mouse on their own, the $\mu$-rhythm desynchronization develops in the frontal, central and parietal neocortical regions, which is more pronounced in the left hemisphere. When the children aged 4-6, 7-9 and 10-12 imitate the biological and non-biological motion no significant additional $\mu$-rhythm modulation is revealed, compared to the execution of movements on their own. In children aged 13-15, the highest sensorimotor rhythm desynchronization is observed during the resercher's hand 
motion imitation. When developing the software for braincomputer interfaces designed for motor function impairment correction, elements of the non-biological objects' movement may be used as visual stimuli, but the older the children, the more effective the presentation of moving biological objects can be for neocortical activation.

\section{References}

1. Rizzolatti G, Fogassi L. The mirror mechanism: recent findings and perspectives. Philos Trans R Soc Lond B Biol Sci. 2014; 369 (1644): 20130420.

2. Hardwick RM, Caspers S, Eickhoff SB, Swinnen SP. Neural correlates of action: Comparing meta-analyses of imagery, observation, and execution. Neurosci Biobehav Rev. 2018; (94): $31-44$

3. Lebedeva NN, Zufman Al, Mal'cev VJu. Sistema zerkal'nyh nejronov mozga: kljuch k obucheniju, formirovaniju lichnosti ponimaniju chuzhogo soznanija. Uspehi fiziologicheskih nauk. 2017; 48(4): 16-28.

4. Fox NA, Bakermans-Kranenburg MJ, Yoo KH, Bowman LC, Cannon EN, Vanderwert RE, et al. Assessing human mirror activity with EEG mu rhythm: A meta-analysis. Psychol Bull. 2016; 142 (3): 291-313.

5. Hobson HM, Bishop DVM. Mu suppression - a good measure of the human mirror neuron system? Cortex. 2016; (82): 290-310.

6. Gundlach C, Muller MM, Nierhaus T, Villringer A, Sehm B. Modulation of Somatosensory Alpha Rhythm by Transcranial Alternating Current Stimulation at Mu-Frequency. Front Hum Neurosci. 2017; (11): 432.

7. Bimbi M, Festante F, Coude G, Vanderwert RE, Fox NA, Ferrari PF. Simultaneous scalp recorded EEG and local field potentials from monkey ventral premotor cortex during action observation and execution reveals the contribution of mirror and motor neurons to the mu-rhythm. Neuroimage. 2018; (175): 22-31.

8. Ulloa ER, Pineda JA. Recognition of point-light biological motion: mu rhythms and mirror neuron activity. Behav Brain Res. 2007; 183 (2): 188-94.

9. Oberman LM, Pineda JA, Ramachandran VS. The human mirror neuron system: a link between action observation and socia skills. Soc Cogn Affect Neurosci. 2007; 2 (1): 62-66.

10. Wohlschlager $A$, Gattis $M$, Bekkering $\mathrm{H}$. Action generation and action perception in imitation: an instance of the ideomotor principle. Philos. Trans. R Soc. Lond., B Biol Sci. 2003; (358): 501-15.

11. Frolov AA, Bobrov PD. Interfejs mozg-komp'juter: nejrofiziologicheskie predposylki i klinicheskoe primenenie. Zhurnal vysshej nervnoj dejatel'nosti. 2017; 67(4): 365-376.

12. Levickaja OS, Lebedev MA. Interfejs mozg-komp'juter: budushhee $v$ nastojashhem. Vestnik Rossijskogo Gosudarstvennogo Medicinskogo Universiteta. 2016; (2): 4-16

13. Lopez-Larraz E, Escolano C, Montesano L, Minguez J. Reactivating the Dormant Motor Cortex After Spinal Cord Injury With EEG Neurofeedback: A Case Study With a Chronic, Complete C4 Patient. Clin EEG Neurosci. 2019; 50 (2): 100-10.

14. Liburkina SP, Vasilev AN, Kaplan AJa, Ivanova GE, Chukanova AS. Pilotnoe issledovanie ideomotornogo treninga $v$ konture interfejsa mozg-komp'juter u pacientov $\mathrm{s}$ dvigatel'nymi narushenijami.

\section{Литература}

1. Rizzolatti G, Fogassi L. The mirror mechanism: recent findings and perspectives. Philos Trans R Soc Lond B Biol Sci. 2014; 369 (1644): 20130420

2. Hardwick RM, Caspers S, Eickhoff SB, Swinnen SP. Neural correlates of action: Comparing meta-analyses of imagery, observation, and execution. Neurosci Biobehav Rev. 2018; (94): $31-44$

3. Лебедева Н. Н., Зусман А. И., Мальцев В. Ю. Система зеркальных нейронов мозга: ключ К обучению, формированию личности и пониманию чужого сознания.
Zhurnal nevrologii i psihiatrii. 2018; 9 (2): 63-68.

15. Larina NV, Korsunskaja LL, Vlasenko SV. Kompleks «Jekzokist'-2» v reabilitacii verhnej konechnosti pri detskom cerebral'nom paraliche $s$ ispol'zovaniem neinvazivnogo interfejsa «mozg-komp'juter». Nervno-myshechnye bolezni. 2019; 9 (4): 44-50.

16. Cannon EN, Yoo KH, Vanderwert RE, Ferrari PF, Woodward AL, Fox NA. Action experience, more than observation, influences mu rhythm desynchronization. PLoS One. 2014; 9 (3): e92002.

17. Mahin SA, Kaida Al, Eismont EV, Mihailova AA, Pavlenko VB; FGAOU VO «Krymskij federal'nyj universitet imeni V.I. Vernadskogo», patentoobladatel'. Sposob opredelenija individual'nogo chastotnogo diapazona mju-ritma JeJeG. Patent RF № 2702728. 09.10.2019.

18. Raymaekers R, Wiersema JR, Roeyers H. EEG study of the mirror neuron system in children with high functioning autism. Brain research. 2009; (1304): 113-21.

19. Lepage JF, Théoret H. EEG evidence for the presence of an action observation-execution matching system in children. Eur $\mathrm{J}$ Neurosci. 2006; 23 (9): 2505-10.

20. Lebedeva NN, Karimova ED, Karpychev VV, Malcev VJu. Zerkal'naja sistema mozga pri nabljudenii, vypolnenii i predstavlenil motornyh zadach - nejrofiziologicheskoe otrazhenie vosprijatija chuzhogo soznanija. Zhurnal vysshej nervnoj dejatel'nosti. 2018; 68 (2): 204-15.

21. Hummel $F$, Andres $F$, Altenmüller $E$, Dichgans J, Gerloff $C$. Inhibitory control of acquired motor programmes in the human brain. Brain. 2002; 125 (2): 404-20.

22. Brown MN, Staines WR. Differential effects of continuous theta burst stimulation over left premotor cortex and right prefrontal cortex on modulating upper limb somatosensory input. Neuroimage. 2016; (127): 97-109.

23. Thorpe SG, Cannon EN, Fox NA. Spectral and source structural development of mu and alpha rhythms from infancy through adulthood. Clin Neurophysiol. 2016; 127 (1): 254-69.

24. Saygin AP, Stadler W. The role of appearance and motion in action prediction. Psychol Res. 2012; (76): 388-94

25. Bonini L, Rozzi S, Serventi FU, Simone L, Ferrari PF, Fogassi L. Ventral premotor and inferior parietal cortices make distinct contribution to action organization and intention understanding. Cereb Cortex. 2010; (20): 1372-85.

26. Filippi CA, Cannon EN, Fox NA, Thorpe SG, Ferrari PF, Woodward AL Motor system activation predicts goal imitation in 7-month-old infants. Psychol Sci. 2016; (27): 675-84.

27. Yin J, Ding $X, X u H$, Zhang F, Shen M. Social Coordination Information in Dynamic Chase Modulates EEG Mu Rhythm. Sci Rep. 2017; 7 (1): 4782

28. Segalowitz SJ, Santesso DL, Jetha MK. Electrophysiological changes during adolescence: a review. Brain Cogn. 2010; 72 (1): $86-100$
Успехи физиологических наук. 2017; 48 (4): 16-28.

4. Fox NA, Bakermans-Kranenburg MJ, Yoo KH, Bowman LC, Cannon EN, Vanderwert RE, et al. Assessing human mirror activity with EEG mu rhythm: A meta-analysis. Psychol Bull. 2016; 142 (3): 291-313.

5. Hobson HM, Bishop DVM. Mu suppression - a good measure of the human mirror neuron system? Cortex. 2016; (82): 290-310.

6. Gundlach C, Muller MM, Nierhaus T, Villringer A, Sehm B. Modulation of Somatosensory Alpha Rhythm by Transcranial Alternating Current Stimulation at Mu-Frequency. Front Hum 
Neurosci. 2017; (11): 432.

7. Bimbi M, Festante F, Coude G, Vanderwert RE, Fox NA, Ferrari PF. Simultaneous scalp recorded EEG and local field potentials from monkey ventral premotor cortex during action observation and execution reveals the contribution of mirror and motor neurons to the mu-rhythm. Neuroimage. 2018; (175): 22-31.

8. Ulloa ER, Pineda JA. Recognition of point-light biological motion: mu rhythms and mirror neuron activity. Behav Brain Res. 2007; 183 (2): 188-94.

9. Oberman LM, Pineda JA, Ramachandran VS. The human mirror neuron system: a link between action observation and social skills. Soc Cogn Affect Neurosci. 2007; 2 (1): 62-66.

10. Wohlschlager $\mathrm{A}$, Gattis $\mathrm{M}$, Bekkering $\mathrm{H}$. Action generation and action perception in imitation: an instance of the ideomotor principle. Philos. Trans. R Soc. Lond., B Biol Sci. 2003; (358): 501-15.

11. Фролов А. А., Бобров П. Д. Интерфейс мозг-компьютер: нейрофизиологические предпосылки и клиническое применение. Журнал высшей нервной деятельности. 2017; 67 (4): 365-76.

12. Левицкая О. С., Лебедев М. А. Интерфейс мозгкомпьютер: будущее в настоящем. Вестник Российского Государственного Медицинского Университета. 2016; (2): 4-16.

13. Lopez-Larraz E, Escolano C, Montesano L, Minguez J. Reactivating the Dormant Motor Cortex After Spinal Cord Injury With EEG Neurofeedback: A Case Study With a Chronic, Complete C4 Patient. Clin EEG Neurosci. 2019; 50 (2): 100-10.

14. Либуркина С. П., Васильев А. Н., Каплан А. Я., Иванова Г. Е., Чуканова А. С. Пилотное исследование идеомоторного тренинга в контуре интерфейса мозг-компьютер у пациентов с двигательными нарушениями. Журнал неврологии и психиатрии. 2018; 9 (2): 63-68.

15. Ларина Н. В., Корсунская Л. Л., Власенко С. В. Комплекс «Экзокисть-2» в реабилитации верхней конечности при детском церебральном параличе с использованием неинвазивного интерфейса «мозг-компьютер". Нервномышечные болезни. 2019; 9 (4): 44-50.

16. Cannon EN, Yoo KH, Vanderwert RE, Ferrari PF, Woodward AL, Fox NA. Action experience, more than observation, influences mu rhythm desynchronization. PLoS One. 2014; 9 (3): e92002.
17. Махин С. А., Кайда А. И., Эйсмонт Е. В., Михайлова А. А., Павленко В. Б.; ФГАОУ ВО «Крымский федеральный университет имени В. И. Вернадского», патентообладатель. Способ определения индивидуального частотного диапазона н-ритма ЭЭГ. Патент РФ № 2702728. 09.10.2019.

18. Raymaekers R, Wiersema JR, Roeyers H. EEG study of the mirror neuron system in children with high functioning autism. Brain research. 2009; (1304): 113-21.

19. Lepage JF, Théoret H. EEG evidence for the presence of an action observation-execution matching system in children. Eur J Neurosci. 2006; 23 (9): 2505-10.

20. Лебедева Н. Н., Каримова Е. Д., Карпычев В. В., Мальцев В. Ю. Зеркальная система мозга при наблюдении, выполнении и представлении моторных задач - нейрофизиологическое отражение восприятия чужого сознания. Журнал высшей нервной деятельности. 2018; 68 (2): 204-15.

21. Hummel F, Andres F, Altenmüller E, Dichgans J, Gerloff C. Inhibitory control of acquired motor programmes in the human brain. Brain. 2002; 125 (2): 404-20.

22. Brown MN, Staines WR. Differential effects of continuous theta burst stimulation over left premotor cortex and right prefrontal cortex on modulating upper limb somatosensory input. Neuroimage. 2016; (127): 97-109.

23. Thorpe SG, Cannon EN, Fox NA. Spectral and source structural development of mu and alpha rhythms from infancy through adulthood. Clin Neurophysiol. 2016; 127 (1): 254-69.

24. Saygin AP, Stadler W. The role of appearance and motion in action prediction. Psychol Res. 2012; (76): 388-94.

25. Bonini L, Rozzi S, Serventi FU, Simone L, Ferrari PF, Fogassi L. Ventral premotor and inferior parietal cortices make distinct contribution to action organization and intention understanding. Cereb Cortex. 2010; (20): 1372-85.

26. Filippi CA, Cannon EN, Fox NA, Thorpe SG, Ferrari PF, Woodward AL. Motor system activation predicts goal imitation in 7-month-old infants. Psychol Sci. 2016; (27): 675-84.

27. Yin J, Ding $X, X u H$, Zhang $F$, Shen M. Social Coordination Information in Dynamic Chase Modulates EEG Mu Rhythm. Sci Rep. 2017; 7 (1): 4782.

28. Segalowitz SJ, Santesso DL, Jetha MK. Electrophysiological changes during adolescence: a review. Brain Cogn. 2010; 72 (1): 86-100. 